\title{
HIOU, SOJA DAN TOLUGBALANGA: \\ NARASI FOTO PENAMPILAN ELITIS PADA BUSANA \\ TRADISIONAL SIMALUNGUN
}

\author{
HIOU, SOJA AND TOLUGBALANGA: \\ PHOTO NARRATIVE OF ELITIST APPEARANCE IN \\ SIMALUNGUN TRADITIONAL CLOTHING
}

\begin{abstract}
Erond L. Damanik
Universitas Negeri Medan

eronddamanik@yahoo.com

Abstract

This study aims to describe and understand the photo narrative of the elitist appearance inherent in Simalungun traditional clothing. The problem of the study focused on the origin and dynamics of clothing which was adapted as traditional clothing. The theoretical reference was adapted from Kees van Dijk and Jean Gelman Taylor that clothing became an appearance that presenting differences. The study was conducted qualitatively with an interpretive approach to 11 photos of colonial archives, selected from 36 photos of elitist appearance. State of the arts was determined based on an anthropological perspective, namely clothing as a social and cultural skin. The finding of this study was that the colonial photo archive was a reference to traditional fashion formulations that reflected elitist appearance. Simalungun traditional clothing is a product of adaptation and commodification from the elements of modernity and locality. Novelty of this study states that traditional clothing is an attribute of multiculturalism to guarantee the diversity of the nation. The contribution of this study confirms the theoretical paradigm used.
\end{abstract}

Keywords: clothing, elitist, appearance, modernity

Abstrak

Tulisan ini bertujuan untuk mendeskripsikan dan memahami narasi foto penampilan elitis yang melekat pada busana tradisional Simalungun. Masalah tulisan difokuskan pada asal usul dan dinamika busana yang diadaptasi sebagai busana tradisional. Acuan teoritis diadaptasi dari Kees van Dijk dan Jean Gelman Taylor yang menyatakan bahwa busana menjadi penampilan yang menyuguhkan perbedaan. Tulisan dilakukan secara kualitatif dengan pendekatan interpretatif terhadap 11 foto arsip kolonial yang dipilih dari 36 foto penampilan elitis. State of the arts ditentukan berdasarkan perspektif antropologi, yakni busana sebagai kulit sosial dan kebudayaan.Temuan tulisan ini adalah bahwa arsip foto kolonial menjadi referensi perumusan busana tradisional yang mencerminkan penampilan elitis. Busana tradisional Simalungun adalah produk adaptasi dan komodifikasi dari unsur modernitas dan lokalitas. Noveltytulisan ini menyebutkan bahwa busana tradisional merupakan atribut multikulturalisme untuk menjamin kebhinekaan bangsa. Kontribusi tulisan ini mengukuhkan paradigma teoritis yang dipergunakan.

Kata kunci: busana, elitis, penampilan, modernitas

\section{Pendahuluan}

Pada pertengahan 2015 silam, muncul jenis topi yang diklaim sebagai 'topi adat' pada etnik Simalungun. Topi adat yang dimaksud adalah gotong dan bulang sulampei. Kemunculan jenis 'topi adat' ini mendadak viral melalui media sosial terutama Facebook. Puluhan pemuda (parana), pemudi (panakboru), maupun orangtua yang menjadi 'friends' penulis tampil berswafoto mengenakan kedua topi itu. Mereka itu adalah anggota komunitas yang menamakan diri sebagai pencinta dan penggiat budaya
Simalungun. Kemunculan 'topi adat' ini mengundang polemik dikalangan masyarakat, elit, dan akademisi berupa sikap menerima dan menolaknya. Beberapa orang mengklaim 'topi adat' tersebut merupakan kultur asli Simalungun sesuai dengan penampilan elit (partongah) pada arsip foto kolonial. Beberapa orang merasa aneh dan tidak tahu menahu dengan 'topi adat' yang viral ini. Sementara itu, beberapa lainnya menolak klaim 'topi adat' Simalungun yang telah disepakati melalui seminar kebudayaan tahun 1964. 
Berdasar pada polemik ini, Lembaga Penelitian Universitas Simalungun Pematangsiantar pada taggal 15 Desember 2015 melakukan seminar bertema "Pemakaian Busana Simalungun: Menuju Kearifan Lokal" dan penulis tercatat sebagai salah satu pemateri. Beberapa peserta di awal seminar tampak mengenakan 'topi adat', tetapi dari pertengahan hingga akhir seminar tidak satupun peserta seminar yang mengenakannya. Mencermati permasalahan ini, muncul sejumlah tanda tanya sekaligus menjadi alasan munculnya tulisan ini, yaitu penggunaan tolugbalanga (jas tanpa kerah berwarna gelap) dan soja (kebaya berwarna putih) yang dipadu dengan hiou (kain tenunan tradisional Simalungun) sebagai bagian dari busana tradisional Simalungun. Busana tradisional ini dilengkapi sejumlah milineris dan aksesoris guna menambah keagungannya. Tulisan ini memfokuskan bahasan pada tradisi berbusana yang menjadi embrio busana tradisional pada orang Simalungun.

Perkembangan berbusana di Simalungun dimulai dari istana (rumahbolon) yang dipraktikkan kaum bangsawan. Mereka adalah keluarga dan kerabat raja-raja maupun kaum terdidik lulusan sekolah kolonial dan Zending di Simalungun. Kelompok sosial ini dianggap memiliki relasi dan kedekatan tersendiri dengan Pemerintah Kolonial. Kaum bangsawan merasa perlu melakukan modernisasi berbusana di tengahtengah dinamika yang terjadi sekaligus membangun interaksi dan relasi dengan Pemerintah Kolonial. Upaya ini adalah politik busana yang dimaksudkan untuk menciptakan dan mengukuhkan status, peran, posisi sosial serta kekuasaannya. Politik busana ini tidak sekaligus meninggalkan unsur lokalitas dengan menyerap seluruh modernitas, tetapi dilakukan secara selektif melalui proses adaptasi dan komodifikasi (Apparudai, 1996).

Komodifikasi ini mencerminkan peminjaman dan peniruan yang dianggap mencirikan diferensiasi, modernitas, dan moralitas. Keseluruhan proses ini menggambarkan rangkaian perkembangan tradisi berbusana yang kemudian diklaim sebagai bagian dari busana tradisional. Busana tradisional tidak menunjuk pada peristiwa atau kejadian otentik upacara adat istiadat, tetapi menyiratkan dorongan romantisme pelestarian kebudayaan asli (Muijzenberg, 1990). Busana tradisional adalah benteng tradisi (Schneider, 1987) atau kesadaran diri di atas kulit busana (Comaroff, 1992). Busana tradisional adalah ekspresi identitas sosial, asal usul, komitmen, dan kesetiaan individu terhadap etniknya (Kuper, 1973).
Busana tidak sekedar penutup tubuh, tetapi menunjuk perbedaan status, peran, posisi sosial serta kekuasaannya. Setiap busana menyuguhkan derajat sosial yang mencerminkan perkembangan sosial dari suatu fase ke fase lain yang menunjuk pada modernitas (Schneider, 1989; Taylor, 1983). Busana menyuguhkan relasi antara kekuasaan politik, ekonomi (kekayaan), dan sosial (wibawa) (K. van Dijk, 2005). Busana tradisional menyuguhkan identitas pemakainya dan tidak semata-mata dimaknai sebagai 'penutup tubuh' tetapi memiliki pluralitas makna berselubung kelas, status, peran, kedudukan, dan jenis kelamin (Taylor, 1983). Selain itu, busana menunjukkan pandangan moral, religius, dan politik pemakainya (K. van Dijk, 2005). Meminjam penyataan bahwa tren berbusana merupakan produk kapitalis yang menyuguhkan proses tiada henti yang memperluas repertoar kaidah berbusana bagi kelompok masyarakat dan membuat busana lain tampak ketinggalan zaman (Wilson, 1985). Pernyataan ini menguatkan bahwa masuknya kultur busana Eropa dan Arab misalnya, turut membentuk repertoar terhadap kultur busana lokal.

Tradisi berbusana di Indonesia menunjukkan tiga pengaruh yaitu: (i) Kultur Pribumi, (ii) Kultur Arab (Islam), dan (iii) Kultur Barat (Kristen) (K. van Dijk, 2005). Ketiga pengaruh ini memunculkan pembedaan penampilan berbusana natives yang memperlihatkan sikap dan pandangan terhadap ketelanjangan natives. Kultur-Pribumi memandang ketelanjangan bukanlah bagian dari ketelanjangan tetapi menunjuk pada taraf berbusana sesuai zamannya. Kultur Arab memandang ketelanjangan sebagai perilaku amoral. Kultur Barat memandang ketelanjangan sebagai kebodohan, kemunduran dan keterbelakangan. Ketiga pengaruh ini menampilkan gaya berbusana yang berbedabeda. Kultur Barat tampak pada busana calvinis dan corolondo yang identik dengan jas, celana, kemeja, sepatu dan topi. Kultur Arab menampilkan toga, turban, baju bodo (baju kurung). Kultur Pribumi menampilkan sarung berupa batik, hiou, ulos, abit,dan berbagai macam sebutannya.

Adanya kedekatan busana tradisional pria dan wanita di Indonesia yakni tolugbalanga (jas tanpa kerah warna hitam) dan soja (kebaya) menunjukkan realitas sosial saling pinjam yang dipadukan dengan sarung (hiou) sebagai unsur lokal. Hal ini mengindikasikan bahwa busana tradisional di Indonesia dipandang sebagai atribut multikultural yang saling adopsi dan dapat 
mengikat kebhinekaan Indonesia. Pencarian terhadap atribut multikultural ini menjadi penting sifatnya untuk menemukan basis pemersatu di tengahtengah kebhinekaan bangsa, ras, agama, bahasa, sejarah asal usul termasuk warna kulit (H. Geertz, 1981). Meminjam istilah kuali pembauran (melting pot) sangat dibutuhkan bangsa Indonesia untuk mentransformasi pluralisme ke multikulturalisme sebagai jaminan terhadap integrasi dan harmoni berbangsa(Glazer, 1963).

Soja (kebaya) dan tolugbalanga (teluk belanga) mencerminkan kedekatan gaya berbusana di Indonesia yang hanya terdapat pada masyarakat yang memiliki tatanan sosial monarhis sedangkan hiou (sarung) mencerminkan atribut lokal yang umum di Indonesia. Ketiga atribut berbusana ini diadaptasi dan dikomodifikasi selama era kolonialisme yang muncul pada penampilan bangsawan sebagai penguasa lokal (zelfbestuur) ataupun pegawai Pemerintah Kolonial (inlandsche bestuur). Penampilan elitis kaum bangsawan dianggap mencirikan modernitas dan menjadi embrio perumusan busana tradisional pascakemerdekaan. Penampilan elitis ini mencitrakan kedudukan dan peran sosial baru sebagai wujud politik busana menanggapi perubahan sosial dan kekuasaan yang terjadi.

Adapun masalah dalam tulisan ini dirumuskan pada pertanyaan: Benarkah busana tradisional merupakan produk adaptasi dan komodifikasi yang menyuguhkan penampilan elitis bangsawan Simalungun? Signifikansi tulisan ini bukan saja bermaksud untuk memahami rangkaian proses kemunculan busana tradisional Simalungun, tetapi juga terkait dengan kelahiran UU No. 5 Tahun 2017 tentang Pemajuan Kebudayaan. Pada orang Simalungun misalnya, gotong-yakni salah satu busana mutlak berupa penutup kepala adat-telah ditetapkan menjadi Warisan Budaya Tak Benda Indonesia (WTB Indonesia) pada tahun 2018 (Harvina, 2017).

\section{Foto sebagai Teks Budaya}

Data-data pada tulisan ini dikumpulkan melalui wawancara tidak terstruktur pada sejumlah budayawan dan cendekiawan Simalungun. Hasil wawancara dijadikan data pendukung terhadap analisis foto yakni sumber data utama tulisan ini. Dalam tulisan ini, arsip foto dianalisis mengikuti model Taylor, Smith, dan Leigh yang menganalisis foto-foto Aceh(Leigh, 1989; Smith, 1997; Taylor, 2008). Sumber foto utama pada tulisan ini berasal dari arsip kolonial yang tersedia daring di laman kitlv.nl, universiteitleiden.nl, dan wereldculturen.nl maupun sumber Nieuwenhuys (Nieuwenhuys, 1998).

Dari penelusuran di laman kitlv.nl ditemukan 745 lembar foto, di laman universiteitleiden.nl ditemukan 824 lembar foto, dan di laman wereldculturen.nl ditemukan 541 lembar foto.Keseluruhan foto pada ketiga laman daring ini menunjukkan persamaan objek dan peristiwa.Setelah dipilah-pilah, ketersediaan foto yang menyuguhkan penampilan elitis hanya 36 lembar, bertahun 1910-1942. Dari 36 foto kemudian dipilih 11 (sebelas)foto sebagai alat analisis dengan pertimbangan: (i) Mencerminkan perubahan busana elitis yang merepresentasi adaptasi dan komodifikasi modernitas dan lokalitas, dan (ii) Mewakili penampilan elitis sesuai konteksnya.

Foto adalah salah satu sumber dan alat bantu analisis kesejarahan (Nordholt, 2008). Foto adalah bukti riil peristiwa masa lalu yang dapat dilihat pada masa kini, yakni citra kebudayaan material untuk dipahami melalui mata. Foto adalah catatan yang direkayasa secara canggih melalui hubungan sekilas antara objek dengan fotografer (Taylor, 2008). Arsip foto sebagai alat analisis memerlukan pemeriksaan seksama karena foto natives cenderung digambarkan statis dan rumit dibanding orang Eropa yang sangat dinamis (Edwards, 1992; Wachlin, 1994).

Analisis foto membutuhkan ketelitian untuk menemukan yang tersembunyi di balik foto (Breman, 1992). Oleh karena itu, analisis foto memerlukan konteks untuk menjelaskan dan menafsirkannya (Taylor, 2008). Selain itu, foto mengisyaratkan pembedaan yaitu 'siapa kita' dan 'siapa mereka', yakni Pribumi dan Eropa. Dibanding foto orang Eropa, foto masyarakat natives cenderung dipotret sebagai proses membedakan (othering) yaitu penduduk asli (natives types) berupa jongos, pelayan rumah, tukang masak, pengasuh anak, kuli, penjaja makanan, gadis penari, petani, upacaranatives ataupun busana bangsawan yang rumit. Kecenderungan aktivitas disuguhkan adalah pembangunan jalan, kantor, toko, jembatan, kereta api, sekolah, bank, hotel, upacara kolonial, penyambutan tamu-tamu kolonial maupun kunjungan pemerintah kolonial ke daerah.

Sumber data melalui wawancara dan arsip foto ditelaah melalui serangkaian proses kategorisasi, tabulasi, dan coding. Analisis 
dilakukan secara mendalam dan pembahasan interpretatif (C. Geertz, 1973) serta penarikan simpulan.Penerbitan UU No. 5 Tahun 2017 tentang Pemajuan Kebudayaan menjadi salah satu dasar dilakukannya kajian untuk tulisan ini untuk mendapatkan apresiasi dan rekognisi dari negara. Regulasi ini memberi ruang pada setiap unit kebudayaan untuk merumuskan busana tradisionalnya sebagai bentuk pengakuan negara terhadap kebhinekaan budaya dan komunitas di Indonesia.

\section{Tradisi Berbusana di Indonesia}

Bagian ini akan menguraikan secara ringkas tradisi berbusana yang dimaksud dalam bagian sebelumnya sebagai gambaran untuk mendapatkan penjelasan tradisi berbusana di Simalungun. Berbusana 'modern' di Indonesia baru terjadi setelah pertemuannya dengan Eropa, yakni pejabat VOC yang hadir pada permulaan Abad 17 M di Batavia (Jakarta). Sebelum abad itu, tidak ditemukan catatan tradisi berbusana pada natives Indonesia. Namun, Kartodirjo menyakini bahwa tradisi berbusana telah ada sebelum era Majapahit yang dibuktikan melalui archaeological findings berupa fuya dan tafa, yakni sisa pakaian dari kulit kayu di pantai barat Irian Jaya (Kartodirdjo, 1977). Selanjutnya, tradisi berbusana semakin berkembang sejak peradaban Hindu dan Buddha yang dibuktikan oleh relief di berbagai candi seperti Borobudur, Prambanan, dan lain-lain (Kartodirjo, 1977).

Catatan resmi berbusana diperoleh dari VOC di Batavia yang hadir sejak 20 Maret 1602. Sumber-sumber VOC mencatat ketelanjangan (nudity) menjadi ciri umum natives (Taylor, 1983, 1988, 2005). Catatan VOC melukiskan cara berbusana natives yang melilitkan kain persegi panjang sebagai penutup tubuh. Kaum wanita melilit kain persegi panjang mulai tubuh bagian bawah hingga bagian dada, sedangkan kaum pria hanya melilitnya di tubuh bagian bawah. Cara berbusana seperti ini sangat umum diperankan pria Jawa, Ambon, dan Bugis di Batavia dan menjadi ciri umum berbusana hingga pertengahan Abad 19 (Graaf, 1742) dan menjadi cara berbusana umum di Pulau Jawa, Minangkabau, Aceh, Betawi, Sunda, Madura, Toba, Simalungun, dan lain-lain.

Sebagian kecil natives wanita di Makassar, Sasak Lombok, Dayak Manyan, Nias, danBali tidak menutup tubuh bagian dada. Kenyataan ini terlihat dari arsip foto kolonial yang dapat diakses secara daring. Bahkan, kenyataan di Bali menjadi dasar penulisan buku 'Pulau Dada Telanjang' (l'Ile des Seins Nus) (Keyser, 1922). Di laman youtube tersedia video bisu yang menggambarkan nudity pada wanita Bali. Di Sumatra Utara, terdapat lukisan nudity wanita Karo yang sedang menggendong anakdi tangga rumahnya (Brenner, 1894). Kenyataan sama ditemukan pada wanita Nias. Bahkan, sejumlah relief berupa patung kayu atau batu di Nias cenderung memperlihatkan nudity. Relief ini menonjolkan lingga dan yoni serta buah dada yang terbuka.

Pejabat VOC yang diutus ke Batavia adalah warga kelas menengah (middle-class) (Nordholdt, 2005; Nordholt, 2002). Namun, dampak keberhasilan ekonominya di Batavia menjadikannya sebagai warga kelas atas (upperclass). Keberhasilan ekonomi ini berdampak pada pengubahan gaya berbusana dari Calvinis yang serba gelap ke Corolondo yang serba putih yang dianggap mengekpresikan kekayaan dan status sosial. Sebenarnya, busana Corolondo adalah busana kelas menengah di Eropa tetapi berubah menjadi busana kelas atas di Indonesia (Taylor, 1983) dan kemudian menjadi busana resmi pejabat VOC dan Pemerintah Kolonial selama di Indonesia.

Selama VOC berdiri (1602-1799), penampilan Corolondo banyak ditiru raja-raja maupun sebagian kecil natives di Pulau Jawa. Peniruan ini muncul sebagai upaya mendefenisikan diri pada situasi sosial yang berubah. Di Batavia ditemukan gejala "masyarakat yang mengubah pakaian mereka" (K. van Dijk, 2005), dan umumnya pengubahan penampilan terjadi di Kampung Kolonial di pesisir Jawa maupun keraton (Nordholdt, 2005). Raja Jawa mengubah penampilannya ke 'busana Barat' pada saat menghadap atau menerima utusan Belanda ( $\mathrm{K}$. van Dijk, 2005). Selain itu, terdapat gejala adaptasi seragam laskar Jawa meniru seragam militer (KNIL) Belanda (Pamberton, 1994). Bahkan, peniruan dilakukan terhadap penentuan perabot rumah tangga, mode dan perhiasan, cara makan, dan lain-lain sepertiyang dilakukanorang Belanda.

Peniruan penampilan berbusana menjadi dasar terbitnya ordonansi berbusana tahun 1658 bagi natives dan Cina di Batavia (Nordholdt, 2005). Ordonansi berbusana dimaksudkan untuk mengatur secara ketat tentang kelas dan status sosial (K. van Dijk, 2005). Namun, ordonansi ini 
bukan saja membatasi peniruan berbusana Barat tetapi juga dimaksudkan untuk pengaturan pemukiman terpisah. Pada setiap pemukiman terdapat aturan bahwa, pemukim harus mengenakan 'pakaian nasional' masing-masing. Melalui ordonansi ini, golongan masyarakat yang dapat meniru cara berbusana Eropa adalah golongan yang memiliki kedekatan dengan VOC, yakni ningrat Jawa ataupun natives Kristen. Setiap natives Kristen di wilayah kendali VOC harus berbusana gaya Eropa karena dianggap menjembatani jarak antara Belanda dan natives (Haan, 1922). Sebaliknya, natives non-Kristen dilarang berbusana Eropa dan diminta setia pada 'pakaian nasionalnya'. Catatan de Haan menyebut bahwa budak dilarang menggunakan bahasa Portugis, mengenakan topi ataupun berjalan di depan umum mengenakan sarung dan kain yang disampirkan di bahunya. Selanjutnya, orang Cina di Bataviadilarang mengadopsi cara berbusana natives dan Eropa. Pelarangan ini muncul karena sejumlah orang Cina mengenakan 'mantel terusan' (Gerstacker, 1855).

Setelah bubarnya VOC, terbit Plakaatboek 1885-1900 yakni ordonansi yang melarang natives Jawa berbaur dengan 'bangsa-bangsa' lain di Batavia. Secara tegas, tertulis pada plakat ini pelarangan kostum 'bangsa lain'. Menurut van Dijk (2005), penerbitan ordonansi berbusana dimaksudkan untuk mengontrol dan mereduksi tindak kejahatan di masyarakat. Menurutnya, seseorang pelaku kriminal akan mudah dikenali dari busana yang dipakainya. Merujuk catatan Taylor (1983), tindak kriminal (pembunuhan dan perampokan) banyak terjadi tahun 1658-1683 dan menjadi dasar munculnyarumah bertembok maupun penggunaan penjaga. Batasan berbusana masih berlaku hingga awal Abad 19, seperti tampak pada pelajar natives di STOVIA yang diwajibkan 'berbusana nasionalnya' (Toer, 1988). Pada awal Abad 20, 'busana nasional' berganti ke corolondo dan menjadi identitas medis yang terus dipakai hingga saat ini. Sejak awal Abad 20, tidak hanya lulusan STOVIA, tetapi lulusan sekolah kolonial dan Zending telah berbusana corolondo yang dianggap sebagai busana kaum terdidik. Kemudian, busana ini diadopsi menjadi busana pelantikan kepala desa, lurah, bupati, walikota, dan gubernur yang merepresentasikan 'peran dan kelas sosial' di masyarakat.

Takluknya Diponegoro pada Perang Jawa (1830) berdampak pada longgarnya ordonansi berbusana. Pada momentum ini, home industri tenunan wanita Jawa diambilalih Pemerintah Kolonial dan menjadi starting pointindustri tekstil yang sebenarnya (Taylor, 1983). Satu dasawarsa kemudian, berdiri pabrik tekstil di Surabaya (1840) dan Pekalongan (1890) yang dimiliki pengusaha wanita berkebangsaan Belanda. Kedua pabrik tekstil ini mengubah kain batik persegi panjang menjadi kebaya (perpaduan kultur Jawa dan Mestizo), celana, dan rok. Produksi pabrik tekstil ini berkembang pesat sejalan dengan Revolusi Industri di Inggris. Pada saat itu, penampilan berbusana di Inggris dan Eropa memengaruhi penampilan berbusana bagi orang Eropa di Pulau Jawa. Misalnya, penciptaan kemeja berupa jas tanpa kerah berwarna gelap (modifikasi setelan jas Mestizo) yang banyak dipakai bangsawan di seluruh Netherland India. Kain-kain produksi Inggris dan India di impor dan diubah menjadi kemeja, jas tanpa kerah, celana, rok maupun kebaya (Taylor, 1983; K. van Dijk, 2005). Di berbagai daerah, pakaian ini dijadikan sebagai busana resmi pemerintah swapraja, pejabat pribumi kolonial di daerah kolonimaupun masyarakat.

Di berbagai daerah, busana-busana ini mengalami sejumlah komodifikasi dan adaptasi. Ningrat Jawa misalnya, mengenakan jas hitam tanpa kerah, kemeja putih yang dibalut sarung serta mengenakan blangkon dan sejumlah aksesoris. Kebaya wanita dibalut dengan sarung serta mengenakan sejumlah aksesoris. Komodifikasi ini menimbulkan gaya berbusana yang unik seperti ditampilkan R.A. Kartini maupun Adipati Djajadiningrat yang mengenakan jas tanpa kerah, kemeja putih, dasi kupu-kupu, sarung, serta blangkon. Keunikan lain tampak pada pemakaian busana setelan warna hitam tetapi memakai blangkon dan sarung. Demikian halnya, pemakaian busana setelan yang dipadu baju bodo (baju kurung) dan mengenakan sandal jepit. Lebih unik lagi, laskar Legion Mangkunegara mengenakan topi khas Romawi, kemeja hitam, sandal tetapi memakai sarung dan menghunus pedang. Pada intinya, pertengahan Abad 19 adalah permulaan Barat 'menghias' natives di Netherland India (K. van Dijk, 2005).

Penampilan berbusana yang diperagakan adipati di pulau Jawa menjadi acuan Pemerintah Kolonial untuk menentukan gaya busana pejabat pribumi di daerah jajahan. Dapat dikatakan, komodifikasi busana 'Barat' menjadi tren dan ciri berbusana di berbagai daerah selama periode kolonialisme. Penampilan ini muncul karena adanya asumsi modernitas berbusana yang 
dipadu dengan milineris dan aksesoris sebagai perlambang kelas, status, dan posisi sosialnya. Cara ini dilakukan untuk membentuk relasi terhadap Pemerintah Kolonial ataupun penegasan terhadap kelas sosial dan kekuasaannya yang bergerak dinamis.

Sebagaimana disebut Taylor (1983), kebaya bukanlah 'kultur asli' Indonesia. Kebaya merupakan produk perkembangan khas tradisi berbusana selama periode kolonial. Kebaya (warna putih untuk wanita Eropa dan motif khas untuk nyai atau selir) terlahir dari adaptasi kultur Keraton Jawa dan Mestizo (Portugis). Pada era kolonial, kebaya dan juga sarung menjadi busana tandingan terhadap busana setelan Barat berwarna putih maupun hitam. Selama periode Rafles di Pulau Jawa, sarung dan kebaya dipindah menjadi busana privat bagi wanita Eropa di Jawa. Kemudian, Rafles memperkenalkan 'busana terusan' khas Eropa yang dikenakan sehari-hari. Pada awal Abad 20, sarung dan kebaya hanya digunakan terbatas oleh wanita natives, sedangkan wanita Peranakan dan Eropa menggunakan 'busana terusan'.

Pada tahun 1942, terjadi perubahan gaya berbusana di Indonesia. Tren berbusana khas Eropa digantikan busana Jepang bercorak seragam militer. Busana ini adalah jas lengan pendek dan celana panjang (safari). Penampilan ini menjadi ciri khas Jepang yang ditularkan kepada 'Barisan Pemuda' didikan Jepang seperti PETA, Heiho, Giyugun, dan lain-lain. Gaya berbusana ini dikenakan Soekarno dengan menambahkan kopiah atau peci (petje) berwarna gelap dan menjadi penampilan khasnya. Pasca kemerdekaan, busana safari dianggap sebagai penampilan resmi pamong praja. Model berbusana ini menjadi pakaian resmi kenegaraan selama Presiden Soekarno.Tren seragam warisan Jepang ini merasuk hingga idiologi seragam dalam penulisan sejarah yaitu dominasi militer dalam sejarah perjuangan bangsa (McGregor, 2008). Berbeda dengan Nordholt (2005) yang memandang bahwa 'demam seragam' warna krem warisan Jepang menunjuk espirit de corps yang belum pernah terjadi selama kolonialisme Belanda. Penampilan ini dianggap tren baru dan lebih leluasa karena setiap orang dapat mengenakannya termasuk laskar-laskar alumni Jepang maupun didikan kadet.

Busana Safari terus dipakai Soekarno dan ditiru pria Indonesia selama Orde Lama. Sementara itu, busana wanita masih tetap mengenakan kebaya dan sarung.Selama pemerintahan Soeharto di Orde Baru, Safari menjadi pakaian resmi kenegaraan yang mencerminkan idiologi militer. Selain itu, terdapat busana setelan (jas) berwarna gelap yang mengesankan partisipan aktif bangsa modern. Pernyataan ini sejalan dengan Wilson bahwa 'busana setelan warna hitam' memiliki pengaruh egalitarian yang kuat dan membuat pria menjadi partisipan aktif dalam bangsabangsa modern. Pakaian ini menjadi busana resmi dalam aktivitas bisnis dan pemerintahan serta hubungan internasional.

Pada Orde Lama, sarung dan kebaya muncul diantara busana elit sebagai 'busana nasional' wanita Indonesia. Namun, kemunculan ini bukan didorong oleh keinginan penyetaraan hak tetapi lebih kepada kekaguman Soekarno terhadap wanita berbusana tradisional (Weringgia, 1995). Kenyataan ini sejalan dengan penjelasan Taylor bahwa wanita yang ditampilkan dalam balutan 'busana tradisional' mengesankan citra masa lalu serta menempatkan wanitaitu ke dalam masa lalu. Tubuh wanita digambarkan menolak Barat dan evolusi historisnya menuju berbagai ruang publik dan kebebasan pribadinya. Sementara itu, laki-laki dengan 'busana setelan' mendeklarasikan diri sebagai pewaris kultur Barat yakni sebagai pemimpin atau pemerintah. Busana setelan didaulat untuk menggambarkan laki-laki sebagai sosok pemimpin yang luwes, terampil, dan beradab. Apalagi dengan adanya dasi yang tergantung di lehernya.

Pada Orde Baru, muncul perpaduan busana berupa celana panjang, jas, kemeja, dan kopiah tetapi tanpa dasi. Penampilan ini bukan lagi mencitrakan sebagai simbol eksklusif nasionalis tetapi menjadi identitas Islam (Nordholdt, 2005). Sementara itu, sarung dan kebaya tetap didaulat sebagai 'busana nasional' wanita yang dianggap mewakili 'tradisi asli' kultur Indonesia. Merujuk catatan Taylor maupun van Dijk, bahwa upaya 'menghias' natives tersebut menghasilkan busana adaptasi dan komodifikasi berupa saling pinjam. Ketika busana dari Surabaya dan Pekalongan diperkenalkan kepada raja-raja di daerah koloni, raja-raja memiliki kesempatan untuk menambah milineris dan aksesorinya. Raja-raja ini merumuskan karakteristik busananya sesuai dengan unsur lokal untuk menunjukkan perbedaan dengan raja-raja dari luar etniknya. Misalnya, jas tanpa kerah yang diadopsi raja-raja di setiap daerah koloni disebut 'Teluk Belanga' (Melayu), 
Tolugbalanga (Simalungun), Jangkep, Beskap, atau Kanigaran (Jawa) atau Linta Baro (Aceh). Demikian halnya busana wanita yakni Kebaya (Jawa) diadopsi oleh etnik lainmenjadi Soja (Simalungun) ataupun Darodaro (Aceh). Pada setiap busana ini ditambahkan milineris dan aksesoris. Misalnya di Simalungun adalah gotong (topi pria), bulang (topi wanita) atau peci (pasomin) khusus bagi pria, suri-suri (selendang), bros, anting-anting, kalung, gelang bertatah emas maupun sarung (hiou tenunan tradisi Simalungun).

\section{Tolugbalanga, Soja, dan Hioudi Simalungun}

Hingga sejauh ini, referensi tentang tradisi berbusana pada orang Simalungun diperoleh dari Anderson yang mengunjungi pantai timur Sumatra termasuk Simalungun pada tahun 1823 (Anderson, 1971). Catatan Anderson menyebut bahwa masyarakat Semilongan atau Semalongan (Simalungun) di Siantar, Tanah Djawa, dan Dolog Silou memiliki barang produksi yang terbuat dari kapas atau kapuk (cotton). Kapas atau kapuk dipintal menjadi benang dan ditenun atau dirajut (wiru) menjadi kain persegi panjang (hiou). Kain-kain tenunan digunakan menjadi penutup tubuh dan sebagian dijual kepada pedagang di bandar (pasar yang buka sepanjang hari). Anderson menulis sebagai berikut.

"the Semilongan are principally dressed in coarse cotton cloths of their own manufactured, 4,5 cubits (2,5 meter) long by 2 cubits (1 meter) wide. They are chiefly of dark blue colour with red or white lines intermixed. The textures is extremely coarse and the cloth hars and wiry to the touch. The cotton is grown in the country and the blue dye is obtained from species of indigo (tarum) which is abundant throughout the island. The lakar and other woods furnish other colour".

Penjelasan Anderson ini memastikan bahwa tradisi memintal benang danmenenun (martonun) sudah eksis di Simalungun sebelum kunjungannya di tahun 1823. Produksi kain tenunan menjadi sumber utama pakaian yang digunakan dengan cara melilitkannya di sekujur tubuh. Cara berbusana ini menjadi embrio berbusana (marpahean) pada orang Simalungun sebelum pertemuannya dengan Barat (Belanda dan Jerman). Meskipun belum memiliki tren busana seperti di Eropa, tetapi setidaknya cara melilitkan kain di tubuh pemakainya menunjukkan tingkat peradaban sesuai zamannya. Selain menyebutkan hasil kerajinan tenunan berupa kain persegi panjang (hiou), catatan Anderson juga menyebut ragam jenisnya pada masyarakat Simalungun yang disebut berbeda dengan kain produksi Batubara. Anderson mencatat sebagai berikut.

"the following is a list of all the different sots of Batta cloths which were procurable in the Assahan country and purchased on account of government, viz: mergum sisi, guru gundang, suri-suri, rinjab, ragi bedouan, sabila garam, sibottar, ragi sihorpa,ragi sihoram, tonompiak, ragi attuanga, iabbit and ragi perbouiac. The Batta cloths brought down the country are ragi tiga, ragi suri-suri, junjong, and ragi seantar, stripped different patterns"

Jenis kain persegi panjang (hiou) yang dicatat Anderson tahun 1823 ini masih ditemukan hingga dewasa ini pada orang Simalungun. Masing-masing jenis hiou ini memiliki pola dan motif yang berbeda-beda. Sumber lain tentang berbusana pada masyarakat Simalungun dicatat Dijk (1894) menulis sebagai berikut.

"busana pria hampir seluruhnya mirip orang Melayu dan terdiri atas baju katun, sebuah kain bawah dan penutup kepala. Celana tidak dikenakan, setidaknya di Tanah Djawa dan Siantar. Ini dilarang, juga orang Asing tidak boleh masuk rumah raja dengan celana panjang. Kaum pria memakai pakaian yang dirajut istrinya dengan warna gelap, modelnya sama dan berkualitas rendah. Kaum wanita memakai kain penutup kepala (bulangbulang) dan mengenakan jumbai yang terbuat dari kumpai yang nampaknya kurang enak dipandang. Mereka mengenakan kain tradisional seperti di Toba dan Silindung, di atas dada di bawah lengan dengan diikat. Juga para wanita yang sudah menikah. Namun ini tidak terjadi di Toba. Di sana wanita yang sudah menikah biasanya tidak menutup tubuh bagian atas. Pada umumnya, penduduk sangat bersih tubuhnya dan menekankan kesucian. Baik pria maupun wanita sering melihat anak-anaknya lebih cerah berkali-kali memandikan mereka setiap hari” (van P. Dijk, 1894).

Dari uraian di atas tampak bahwa hingga tahun 1894, gaya berbusana orang Simalungun masih sama seperti catatan Anderson tahun 1823 yakni melilitkan kain persegi panjang untuk menutupi tubuhnya. Cara melilitkan kain untuk menutup tubuh wanita disebut dengan marabit datas (melilitkan kain hingga atas dada di bawah lengan hingga lutut). Kepalanya tertutup dengan 
topi yang disebut bulang-bulang. Kaum pria mengenakan kain katun untuk menutup tubuh bagian bawah serta mengenakan penutup kepala. Pada busana itu terdapat aksesoris dan milineris seperti dicatat van Dijk (1894) sebagai berikut.

"sebagai perhiasan, pria dan wanita memakai cincin di jarinya. Senjata terdiri atas tombak, senapan dengan batu api dan pedang kecil dalam sarung kayu. Dari luar dibungkus dengan kain merah atau hijau. Selanjutnya, pisau besar dan kecil juga kapak, umumnya dibawa oleh hampir setiap masyarakat Simalungun dari kasta rendah, digunakan di ladang dan merupakan senjata penting di hutan. Dalam kondisi darutat, menjadi senjata ampuh di tangan yang trampil. Namun, biasanya kapak ini sangat panjang dan lebar dan berat serta di asah secara tajam. Juga kaum wanita yang melakukan pekerjaan ringan di ladang hanya diperlengkapi dengan parang. Demikian, apabila mereka pergi dari kampungnya menuju sawah. Selain kain, kepala pria mengenakan banyak kopiah bulat dengan berbagai warna dan dihiasi dengan berbagai cara. Jelas bahwa pada umumnya cara berpakaian tradisional lenyap digantikan dengan cara Melayu. Ini khususnya terjadi di daerah Tandjung Kasau dimana pria dan wanita telah menerima cara berpakaian penduduk pantai. Kaum pria juga berkain dan kaum wanita memakai baju dan kebaya"

Sumber lain tentang marpahean diperoleh dari catatan Saragih (1936) tentang gaya berbusana Rondahaim Garingging (1857-1891), penguasa lokal (raja) dari Kerajaan Raya, Simalungun yaitu sebagai berikut.

"tong do ia marhiou ragi panei anjaha marbaju-baju hiou sitora birong, pargorongni pe tong ibahen popuponi, herbang $i$ lobei songon na loju hu pudi. Tong do homa ibahen doramani dua kamata bani gotongni in. Hadang do homa surisuri nanggar suasah" [beliau selalu mengenakan kain ragi panei dengan baju hiou sitora berwarna gelap. Kepalanya tetap tertutup gotong, melebar di depan dan agak rendah di belakang. Demikian pula ia tetap menggunakan doramani yakni hiasan penutup kepala sebanyak dua buah. Selain itu, ia tetap menggunakan selendang dari kain surisuri nanggar suasah] (Saragih, 1936).

Jadi, sebelum pertemuan orang Simalungun dengan Barat, masyarakat ini telah mengenal teknologi mengolah kapas menjadi benang. Kemudian, benang ini ditenun atau dirajut menjadi kain persegi panjang. Setiap kain ini memiliki pola atau motif (pinar) berwarna yang diperoleh dari pewarna alami yakni indigo. Produksi tenunan ini dipergunakan untuk menutup tubuh wanita dan laki-laki ataupun dijual kepada pedagang asing. Pengetahuan menenun di Simalungun adalah pengaruh kebudayaan Hindu (India) yang masuk ke Sumatra Utara pada Abad 11 (Guillot, 2002; Niessen, 1993, 2009; Parkin, 1978; Perret, 2015; Reid, 1992). Peradaban bukanlah sesuatu yang asli dari daerahnya tetapi adalah peradaban yang hidup dan berkembang karena diserap dari luar (Fischer, 1964). Karena itu, kerajinan tenun, memintal benang, dan merajut benang merupakan peradaban Simalungun yang berkembang karena diserap dari luar.

Keterampilan martonun pada Simalungun adalah pekerjaan kaum wanita. Keterampilan ini ditemukan merata pada kaum wanita hingga sebelum era kolonialisme. Bahkan, setiap istriistri raja (nassipuang) harus memiliki keterampilan martonun. Kenyataan ini dapat dilihat dari adanya pattangan puangbolon (tempat khusus permaisuri) pada setiap istana (rumahbolon) yakni tempat untuk menenun atau merajut kain oleh permaisuri. Contoh konkretnya masih dapat dilihat hingga saat ini di istana Kerajaan Purba di Pamatangpurba. Pada arsip kolonial, ditemukan 11 foto yang memperlihatkan perempuan Simalungun sedang menenun kain di Tanohjawa, Purbasaribu, Dologsilou, dan lain-lain.

Ketika Zending Jerman (RMG) bekerja di Pematangraya pada tahun 1903 dan kolonialisme di Simalungun pada tahun 1907, - nudity pada natives diubah menjadi menggunakan 'busana modern'. Busana ini adalah produksi Surabaya dan Pekalongan yang diimpor Zending RMG ke Pematangraya. Kemudian, sejak tahun 1907, Pemerintah Kolonial memasok kain produksi Pulau Jawa ini ke seluruh pusat-pusat koloni (partuanon) di Simalungun, yakni Siantar, Tanohdjawa, Purba, Nagasaribu, Paneitongah, dan Dolog Silou. Tentu saja, penggunaan busana modern ini pertama-tama diadopsi oleh raja-raja yakni bangsawan Simalungun. Penampilan elitis ini ditularkan kepada masyarakat dari pusat kerajaan (pamatang) ke desa induk (partuanon), kesatuan beberapa kampung (nagori) dan kampung (huta). Kemudian, penampilan ini diikuti oleh seluruh masyarakat (kawula) di seluruh Simalungun.

Sebagai catatan, kolonialisme di Simalungun didorong oleh keinginan ekspansi perkebunan 
kolonial. Walaupun sudah dicoba diekspansi sejak 1885 tetapi kolonialisme sesungguhnya baru terjadi tahun 1907 (Marihandono, 2009). Pascapemakzulan dan internering (pembuangan) Sang $\mathrm{Na}$ Ualuh Damanik (raja Siantar) ke Bengkalis tahun 1906, barulah Korte Verklaring oleh 7 Raja di Simalungun ditandatangani tahun 1907 (Damanik, 2016). Sebelumnya, pada tahun 1903 Zending Jerman telah bekerja di Pamatangraya yang identik dengan 'memanusiakan manusia' melalui agama, kesehatan, pendidikan, dan keterampilan hidup (Dasuha, 2003).

Misi Jerman yang melihat nudity sebagai kebodohan, kemunduran, keterbelakangan, dan amoral perlambang ketidakberadaban (uncivilized) dan mereka harus diubah menjadi manusia beradab (civilized) (Damanik, 2017a). Dengan kata lain, kehadiran bangsa Barat di Simalungun ingin mengubah ketelanjangan (nudity) menjadi manusia beradab melalui busana modern. Selain itu, kehadiran Pemerintah Kolonial pascakorte verklaring mengubah banyak hal, seperti pendidikan dan kesehatan modern, birokrasi dan pemerintahan swapraja, hukum tanah, pembangunan infrastruktur, perkantoran, perdagangan, transportasi, irigasi, pertanian, dan perkebunan (Tideman, 1922).

Keterbukaan Simalungun berdampak pada masuknya sejumlah besar orang Eropa dan migran lokal lainnya seperti Toba, Mandailing, Jawa, dan India. Wilayah Simalungun ditetapkan menjadi onderafdeeling (1908) dan afdeeling (1912). Sementara itu, Siantar ditetapkan sebagai gemeente (1917). Penetapan ini berdampak pada hilangnya daerah-daerah Simalungun karena digabungkan ke wilayah lain di Karo, Serdang, Bedagei, kota Padang (Tebingtinggi), Batubara, dan Asahan (Damanik, 2018). Selanjutnya, daerah-daerah ini bukan lagi menjadi homeland orang Simalungun tetapi menjadi wilayah persebaran budayanya (culture area).

Padatnya interaksi masyarakat di Simalungun dan daerah pesisir seperti Tanohjawa, Batubara, dan Bandar yakni wilayah yang bersinggungan dengan Melayu menjadi awal menguatnya labelisasi 'batak'di Simalungun (Perret, 2010). Labelisasi ini berdampak pada cara berbusana bagi orang Simalungun yang bermukim di pesisir timur Sumatera. Pada bagian ini, busana menjadi salah satu alat untuk membedakan diri yakni Melayu dan Simalungun. Orang Simalungun yang berinteraksi dengan Melayu di pesisir mengubah penampilannya menjadi seperti orang Melayu. Misalnya, orang Simalungun di Bandar telah menggunakan baju kurung yang mencerminkan Islam. Pemerintah Kolonial menyebut orang Simalungun sebagai Batak, dan label ini sangat asing baginya. Selain terdengar aneh, orang Simalungun tidak pernah mengenal konsep ini dan tidak ditemukan catatan pada sejumlah manuskrip-manuskrip tua yang dimilikinya (Damanik, 2018). Peta Simalungun tahun 1883 tidak mencantumkan kata Batak kecuali gebied der orang Purba, gebied der orang Raya, dan gebied der orang Silimahuta(Hagen, 1883).

Orang Simalungun Islam di Bandar, Padang, Bedagei, dan Tanohjawa menyimpan busana Melayu di rumahnya masing-masing (Simon, 1906). Busana Melayu itu hanya dipakai apabila bermaksud mengunjungi atau berdagang ke pesisir selat Malaka Interaksi pesisir dan pedalaman di Simalungun seperti Tanjung Kasau, Bandar, Pardagangan, Sarbelawan, Tanohjawa, Bedagei, dan Padang menjadi dasar bagi orang Simalungun untuk memilih identitas Melayu (van P. Dijk, 1894). Faktor agama menurut van Dijk menjadi alasan utama bagi mereka untuk meninggalkan identitas lamanya pada saat menerima identitas yang baru. Busana 'tradisi asli' Simalungun di Tanjung Kasau dan beberapa daerah lain telah hilang dan digantikan dengan cara berbusana Melayu (van P. Dijk, 1894). Mereka ini mengubah penampilannya melalui adopsi berbusana Melayu seperti di Tandjung Kasau yakni Simalungun yang telah menjadi Melayu karena pengaruh agama Islam (J. Kroesen, 1897; R.Kroesen, 1904).

Pada saat pendudukan kolonial Belanda, terdapat kesulitan untuk mengidentifikasi antara penduduk Melayu dan Simalungun pada saat berada di bandar-bandar dagang. Kesulitan lain ditemukan untuk membedakan bangsawan Simalungun yang banyak meniru busana ningrat tetangganya yakni Melayu Batubara, Deli, dan Serdang Bedagei. Menurut Perret (2010), peniruan ini terjadi karena adanya asumsi bahwa busana ningrat Melayu dianggap lebih tinggi harkat dan martabatnya serta menyimbolkan modernitas. Melihat gejala ini, Pemerintah Kolonial, seperti diberitakan suratkabar Pewarta Deli tertanggal 23 Maret 1917, membuat kebijakan berbusana bagi raja-raja Melayu, Simalungun, dan Karo. Disebutkan, Koopman yakni controleur (kontrolir) Belanda di Boven Serdang memanggil seluruh raja-raja dari ketiga wilayah ini untuk memutuskan busana mereka di Bangunpurba. 
Kebijakan ini dilakukan Koopman karena sejak bertugas pada bulan Januari 1917 kesulitan membedakan raja-raja di wilayah kekuasaannya. Pada saat itu, raja-raja dari ketiga wilayah ini memilih Corolondo sebagai busana resmi (jas putih) yang dipadu dengan sarung pelekat Madras dan Batubara, kopiah beludru hitam dan sepatu kuning. Pada pertemuan raja-raja di Bangunpurba pada bulan Maret 1917 diputuskan bahwa busana raja Simalungun dan Karo menggunakan busana sultan Melayu. Kemudian, Koopman menyampaikan permohonan raja-raja ini kepada jaksa Kerapatan Boven Serdang, Kejuruan Karo, dan Partuanon Timor (Simalungun) untuk menentukan jenis topi yakni peci (pasomin) (Perret, 2010). Pada akhirnya, seluruh raja-raja dari Simalungun dan Karo mengganti seluruh pakaian mereka terdahulu yang dianggap tidak bernilai, yang cenderung serupa dengan pakaian orang Dayak, menjadi seragam yang lebih menunjukkan posisi mereka di masyarakat maupun dihadapan Pemerintah Kolonial.

Sejak saat itu, raja-raja Simalungun mengenakan busana seperti dikenakan sultan Melayu, yakni kemeja hitam tanpa kerah, celana hitam, sepatu hitam, dan mengenakan kopiah seperti dikenakan bangsawan Makassar. Busana seperti ini dipakai saat bertugas sebagai pemerintah swapraja. Busana ini dikombinasikan dengan aksesoris dan milineris guna menambah keagungan busana. Namun, saat bertugas sebagai pegawai kolonial, mereka harus menggunakan busana corolondo. Busana ini mengisyaratkan kedekatan antara Pemerintah Kolonial dengan Pemerintah Swapraja, yakni mereka yang dianggap menjembatani jarak antara kepentingan kolonial dengan natives. Selain itu, kaum intelektual lulusan sekolah Zending mengenakan busana corolondo yakni perlambang kelas menengah baru di Simalungun. Kepada mereka yang bertugas sebagai rohaniawan ini ditambahkan jubah (khas Italia) yakni pelengkap busana yang mencerminkan religius.

Berdasar uraian di atas terdapat tiga klasifikasi pengaruh berbusana di Simalungun, yaitu (i) Pengaruh Eropa (Belanda dan Jerman) yakni corolondo dan jas tanpa kerah berwarna gelap dan celana yang tampak pada bangsawan yakni raja-raja dan kaum terdidik dari lembaga pendidikan kolonial dan Zending Jerman, (ii) Pengaruh Arab-Melayu yakni kemeja kurung yang tampak pada orang Simalungun yang berbatasan dengan daerah pesisir Melayu di Tanjung Kasau, Pardagangan, Bandar, Serdang
Bedagai dan Kota padang, dan (iii) Pengaruh lokal yakni penggunaan hiou yang dililitkan pada bagian bawah tubuh (hiou ragi panei) dan selendang (suri-suri nanggarsuasah) yang tergantung di bahu. Ketiga pengaruh ini terangkum pada busana tradisional Simalungun yang mengkombinasikan komponen busana mutlak yakni jas tanpa kerah berwarna gelap (tolugbalanga), kebaya (soja) yang dibalut dengan hiou. Pakaian mutlak ini dipadu dengan sejumlah milineris dan aksesoris bertatah emas untuk menambah keagungan busananya.

\section{Narasi Foto Busana Tradisional Simalungun}

Perumusan busana tradisional tidak menunjuk pada ketelanjangan (nudity) seperti pada saat sebelum pertemuannya dengan Barat. Perumusan busana tradisional ini mencerminkan adaptasi ataupun komodifikasi. Adaptasi dilakukan guna meminjam atribut modernitas, sedangkan komodifikasi dimaksudkan untuk membentuk diferensiasi dan pendefensian diri. Karena itu, upaya adaptasi dan komodifikasi busana mencerminkan ekspresi identitas (Lurie, 1992). Di dalam busana ini terdapat pluralitas makna (Taylor, 1983) dan menjadi kulit sosial dan kebudayaan (Wilson, 1985). Adaptasi dan komodifikasi ini menunjukkan penerimaan (acceptance) orang Simalungun terhadap kultur baru yang dibawa oleh sejumlah orang Eropa selama periode kolonialisme.

Pengaruh Barat, yakni Belanda dan Jerman,jelas tampak pada penampilan elitis partongah Simalungun, berupa dikenalnya busana setelan berupa jas berwarna gelap, jas tanpa kerah (hasil komodifikasi), ataupun corolondo (busana setelan berwarna putih). Busana ini dipakai kaum bangsawan dan selanjutnya diikuti oleh sejumlah kecil orangorang terdidik yang lulus dari sekolah kolonial dan Zending. Pengaruh Islam (Melayu) tampak pada pemakaian kemeja kurung yang umumnya dipakai orang-orang Simalungun yang berbatas dengan orang Melayu seperti di Tanjung Kasau, Bandar, Pardagangan, Deliserdang, dan Padang. Sementara itu, kultur lokal tampak pada pemakaian hiou sebagai penutup tubuh bagian bawah ataupun selendang yang tersampir di bahu. Penggunaan tolugbalanga dan soja memperlihatkan peralihan berbusana dari ketelanjangan ke pakaian modern yang sangat dimungkinkan oleh kolonialisme. Hingga kini, kedua jenis pakaian ini terus dipakai dan 
dirumuskan sebagai bagian dari pakaian tradisional orang Simalungun.

Penggunaan busana-busana itu tidak terlepas dari posisi dan kelas sosial penggunanya pada era kolonialisme: (i) Bangsawan Simalungun sebagai zelfbestuur yang tampil dengan balutan hiou terhadap tolugbalanga dan soja serta sejumlah milineris dan aksesoris, (ii) Bangsawan Simalungun sebagai pegawai kolonial yang tampil dengan busana corolondo, (iii) Intelektual (kaum terdidik) Simalungun, yakni kelas sosial baru karena pendidikan kolonial dan Zending yang tampil dengan busana corolondo dan jubah, (iv) Masyarakat Simalungun Kristen yang pada umumnya mengenakan soja (kebaya) dan hiou (pengganti rok) bagi wanita dan kemeja putih serta celana bagi pria, dan (v) Masyarakat Simalungun Islam yang tampil dengan kemeja kurung pada beberapa wilayah yang berbatas dengan wilayah Melayu. Penggunaan busana baru ini mencerminkan upaya Barat menghias natives Simalungun dari ketelanjangan dan mengenalkan mereka pada tatanan baru yakni peradaban modern. Berikut ini adalah analisis terhadap 11 (sebelas) foto yang mencerminkan penampilan elitis pada busana tradisional Simalungun.

\section{Gambar 1}

Penampilan Tandjarmahei Tambak dari Dolog Silou, 1910

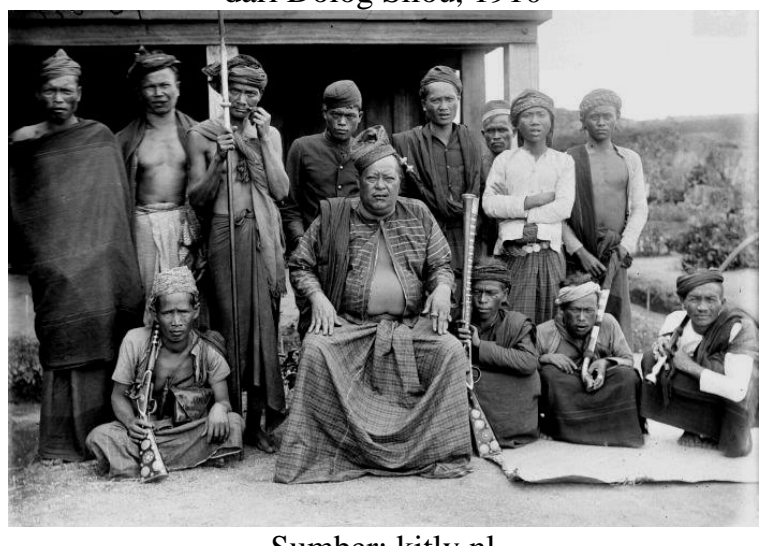

Sumber: kitlv.nl

Foto pada gambar 1 menunjukkan Tanjarmahei Purba Tambak, raja dari Dolog Silou bersama para penglima bertahun 1910 . Foto ini tidak tampak alamiah dan cenderung by design oleh fotografer. Busana yang dikenakan masih menunjukkan pengaruh lokal berupa penggunaan hiouragi panei berwarna gelap dengan liris yang lebih gelap di kedua sisinya. Penutup kepala yang dipergunakan masih sederhana yang dililit di kepala tanpa pola khusus. Sebagian dari panglima telah mengenakan kemeja putih dan hitam yang dilengkapi dengan kancing. Tampak diantaranya memegang tombak, pedang, dan bedil laras panjang. Raja digambarkan duduk di tengah, menggunakan kemeja hitam dengan perut terbuka, mengenakan sarung (hiou) dan penutup kepala yang memiliki doramani (mahkota) dua tingkat. Penampilan elitis ini adalah foto tertua yang ditemukan pada arsip kolonial yang menggambarkan revolusi berbusana pada partongah Simalungun pada periode awal kolonialisme. Foto ini memperlihatkan Tanjarmahei Tambak sebagai pemerintah swapraja di daerah koloni Belanda.

\section{Gambar 2}

Penampilan Rahalim Pakpak dari Purba, 1914

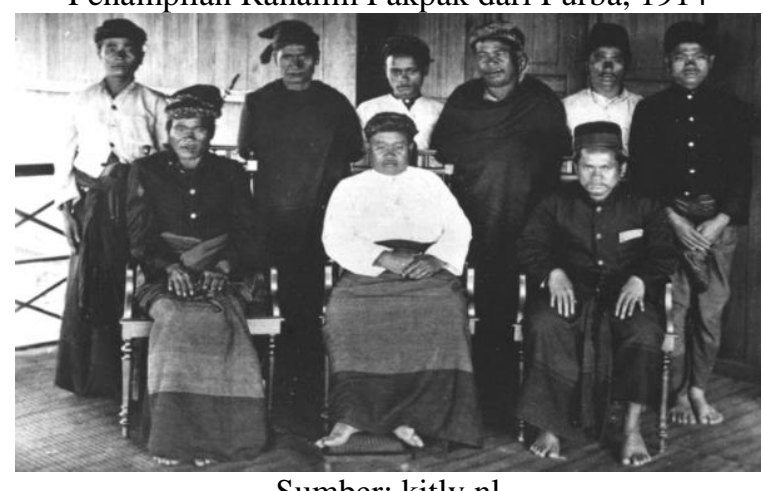

Sumber: kitlv.nl

Foto pada gambar 2 adalah Rahalim Purba Pakpak, Raja dari Purba bersama para panglimanya. Foto inipun tampak by design pada salah satu halaman istana (rumahbolon) Kerajan Purba di Pematangpurba. Arsip foto bertahun 1914 ini menunjukkan gaya berbusana kemeja putih lengan panjang (komodifikasi corolondo) tetapi mengenakan sarung berupa hiou ragi panei dan tanpa alas kaki. Beberapa panglima tampak mengenakan kemeja hitam yang memiliki kancing berupa bros, serta penutup kepala yang memiliki motif-motif khusus. Beberapa panglima juga tampak menggunakan pasomin, sejenis peci (kopiah) yang diadaptasi dari bangsawan Makasar. Penampilan ini tampak sudah lebih maju dari penampilan Tanjarmahei Purba Tambak yang dipotret di Dologsilou tahun 1910. Foto ini menunjukkan Rahalim Pakpak sebagai penguasa swapraja di daerah koloni Belanda.

Foto pada gambar 3 adalah penampilan Ragaim Purba Tambak yakni Raja Dologsilou. Foto by design ini dibuat tahun 1935 di depan halaman Rumahbolon Kerajaan Dologsilou. Ragaim Tambak diperlihatkan berdiri di tengah mengenakan kemeja berwarna gelap dan menggunakan hiou ragi panei pengganti celana, mengenakan suri-suri di bahu kiri serta penutup 
Gambar 3

Penampilan Ragaim Tambak dari Dologsilou, 1935

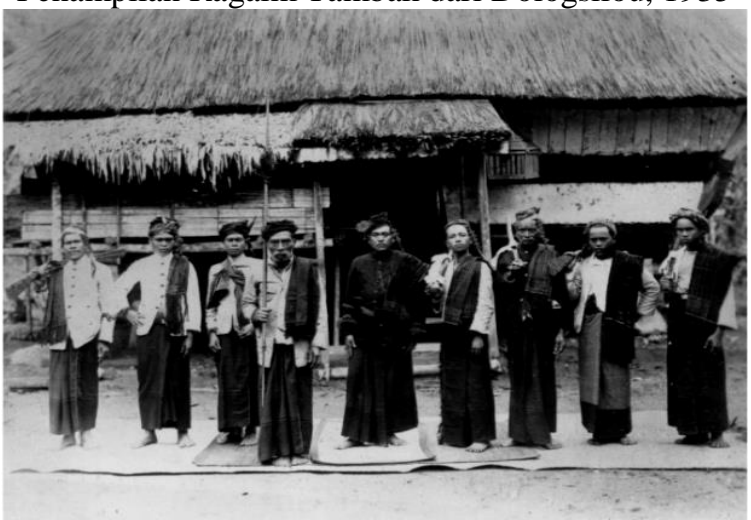

Sumber: kitlv.nl.

kepala dengan pola tertentu serta menggunakan kelopak bunga matahari yang terbuat dari logam serta doramani bertatah emas. Doramani tersebut dibuat tujuh tingkat menggambarkan 7 kerajaan Simalungun yang saling bersaudara. Para panglima dipotret menggunakan kemeja putih lengan panjang, menggunakan bros, dan selendang. Mereka juga memiliki penutup kepada yang tidak memiliki pola dan beberapa diantaranya tampak menggunakan doramani. Setiap panglima ini memegang senjata berupa pedang dan bedil laras panjang. Partongah dari Dologsilou ini berfoto di atas tikar pandan yang menunjukkan keaslian kultur Simalungun pada periode kolonialisme. Foto ini menunjukkan Ragaim Tambak sebagai zelfbestuur di daerah koloni Belanda dengan busana yang rumit.

\section{Gambar 4}

Penampilan Sawadim Damanik dari Siantar, 1935

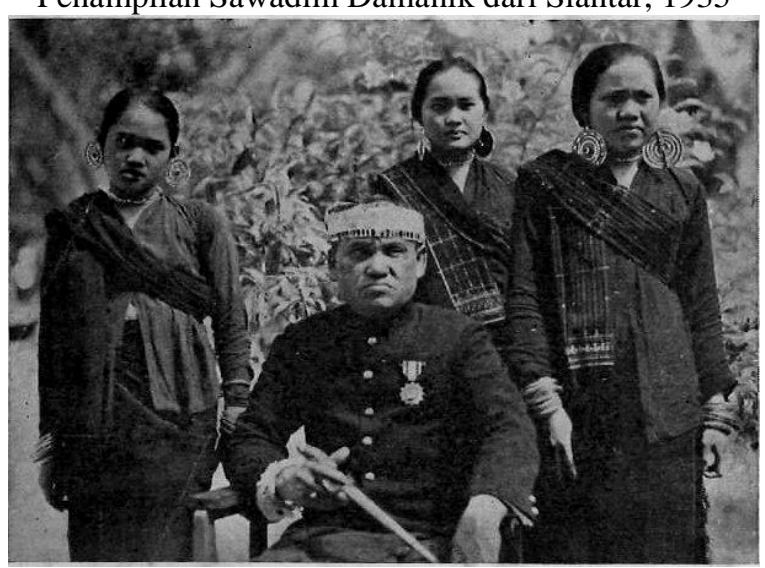

Sumber: kitlv.nl

Gambar 4 memperlihatkan Sawadim Damanik, pemangku raja Siantar dan ketiga putrinya tahun 1935. Foto inipun tidak tampak alamiah tetapi merupakan skenario (by design) sang fotografer pascaupacara pemberian tanda kesetiaan kepada Sawadim Damanik. Raja diperlihatkan mengenakan busana berupa jas tanpa kerah (tolugbalanga) dengan bros, mengenakan penutup kepala (gotong) yang memiliki motif hias serta hiou ragi panei yang dililitkan di luar celana. Ia juga tampil mengenakan sepatu, serta aksesoris berupa pisou halasan (senjata). Di dada sebelah kiri menempel satya lencana kesetian yakni trow van dienst dari Kerajaan Belanda. Sementara ketiga putrinya tampak mengenakan soja (kebaya) warna gelap, mengenakan hiou ragi panei sebagai rok, selendang (surisuri), dan aksesoris telinga (sinokkod). Namun, ketiga putrinya tidak mengenakan penutup kepala (bulang). Foto ini memperlihatkan Sawadim Damanik sebagai zelfbestuur dengan busana yang rumit. Meskipun dirinya mendapat tanda bintang kesetiaan, tetapi busana yang digunakannya tetap menempatkan dirinya sebagai orang yang statis.

\section{Gambar 5}

Penampilan Bosar Sumalam Dasuha dari Panei, 1935

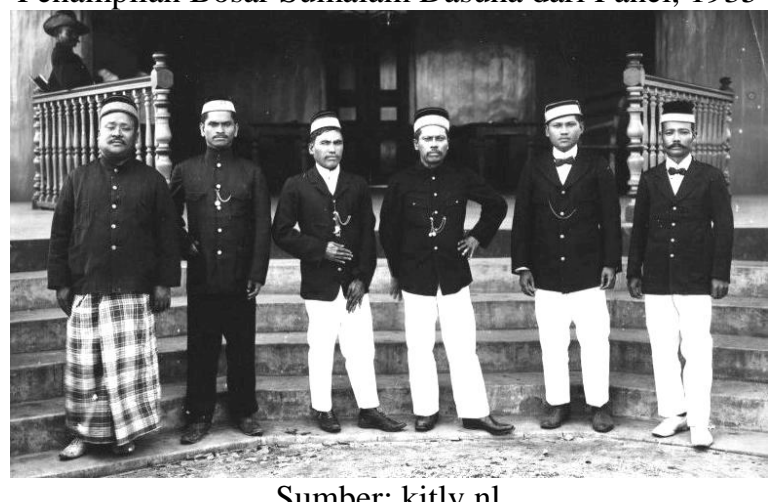

Foto pada gambar 5 memperlihatkan Bosar Sumalam Dasuha dari Panei pada tahun 1935 di halaman rumahbolon di Pamatangpanei. Bosar Sumalam Dasuha tampil dengan kemeja berwarna gelap yang memiliki bros serta memakai kopiah (pasomin). Namun, bagian bawah tubuhnya mengenakan sarung menggantikan celana serta memakai sepatu. Sementara yang lainnya adalah raja-raja Simalungun dan Jaksa Kerapatan yang tampil dengan kemeja tanpa kerah, bros serta rantai busana. Mereka ditampilkan mengenakan celana putih dan hitam serta mengenakan sepatu. Keselurhan bangsawan dipotret menggunakan pasomin sebagai penutup kepala. Foto ini memperlihatkan hilangnya pakaian Simalungun dari bangsawan. Potret ini menyuguhkan bangsawan Simalungun sebagai pejabat kolonial (inlandsche bestuur) di daerah koloni Belanda. 
Gambar 6

Penampilan Raja-Raja Simalungun, 1938

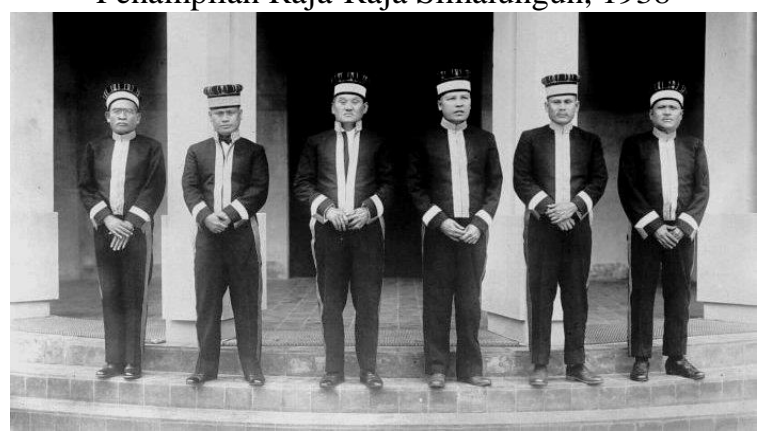

Sumber: kitlv.nl

Foto pada gambar 6 memperlihatkan enambangsawan Simalungun sebagai pegawai pamong prajayaitu raja merangkap tugas sebagai bestuur. Penampilan ini sama sekali tidak menunjukkan karakteristik Simalungun, baik dari topi, kemeja, celana, maupun sepatu yang digunakan. Foto bertahun 1938 ini dipotret secara sengaja (by design) di teras gedung Kerapatan Na Bolon Simalungun di Pamatangsiantar. Penampilan ini mengindikasikan penerimaan kultur Barat di Simalungun yang menyuguhkan kedekatan-kedekatan sosial sekaligus meredefenisi posisi sosial penggunanya di masyarakat.

\section{Gambar 7}

Penampilan kaum terdidik Simalungun, 1940

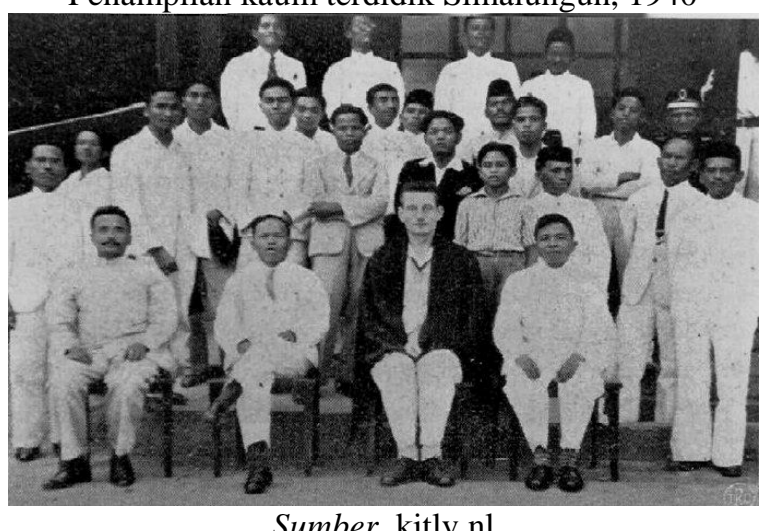

Foto pada gambar 7 memperlihatkan kelas menengah (middle class) baru di Simalungun. Foto bertahun 1940 pada saat pembangunan Museum Simalungun Pamatangsiantar ini memperlihatkan sejumlah intelektual Simalungun yang lulus dari sekolah Zending di Tarutung (Tapanuli Utara) dan Seminari Jakarta. Mereka adalah J. Wismar Saragih dan Djason Saragih. Mereka duduk di samping kanan Vorhooeve, ahli linguistik Belanda yang sedang mengkaji manuskrip Simalungun. Di samping kri adalah Gomok Saragih, yakni raja dari Raya. Mereka tampil dalam busana setelan berwarna putih (corolondo) sebagai perlambang kelas menengah di Simalungun. Foto ini dipotret di teras Gereja HKBPS Jalan Sudirman Pematangsiantar.

\section{Gambar 8}

Penampilan Gomok Saragih dari Raya menyambut Karneebeck, 1941

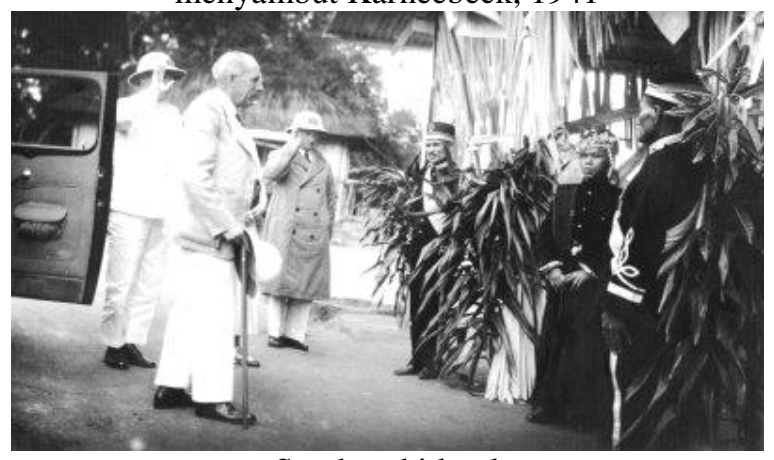

Sumber: kitlv.nl

Foto pada gambar 8 memperlihatkan Gomok Saragih, Raja Raya menyambut H.N. Karneebeck (Menteri Negara Kolonial) di Pamatanraya tahun 1941. Pada foto, Gomok Saragih ditampilkan mengenakan busana lengkap yang dianggap mencirikan Simalungun yakni hiou ragi panei (pengganti celana), jas tanpa kerah berlengan panjang berwarna gelap yang memiliki bros, mengenakan gotong (topi) yang memiliki motif khas, doramani bertatah emas, serta menggunakan selendang (suri-suri) di bahu kirinya dan sepatu. Sebuah penampilan yang kontras berbeda dengan Karneebeck yang tampil mengenakan busana serba putih. Gomok Saragih tampak menyambut tamu Belanda-nya di ruangan yang sudah dihiasi dengan janur kuning, silanjuyang, dan pohon pisang-sebuah hiasan yang biasa dipakai orang Simalungun pada saat pesta sukacita (malas ni uhur).

\section{Gambar 9}

Penampilan panakboru Dologsilou, 1937

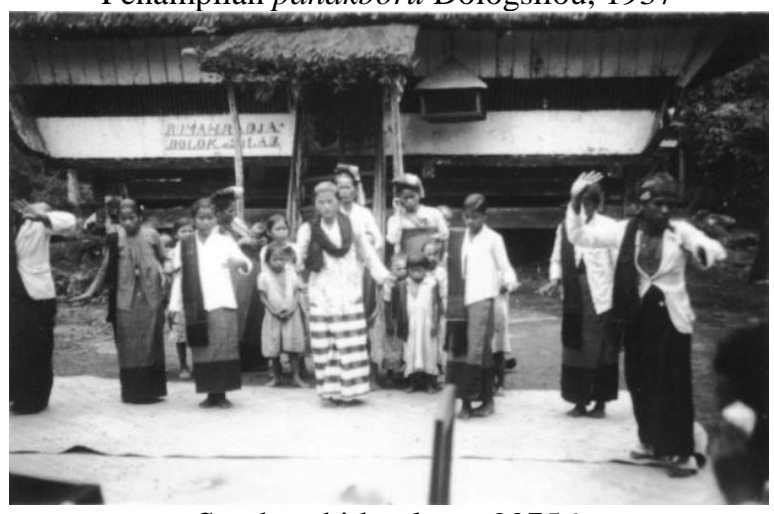

Sumber: kitlv.nl, no. 99756

Foto pada gambar 9 menunjukkan penampilan puangbolon (permaisuri) dan sejumlah anak gadis (panakboru) serta kerabat menari (manortor) di halaman Rumahbolon Kerajaan 
Dologsilou. Tampak permaisuri mengenakan kebaya (soja) dan sarung serta mengenakan surisuri dibahunya. Ia tanpak tidak mengenakan penutup kepala (bulang). Sejumlah perempuan lainnya tampak mengenakan hiou ragi panei, soja berwarna putih, serta suri-suri yang disematkan di bahu kiri. Sebagian dari mereka tanpak mengenakan penutup kepala (bulang) berwarna hitam dan putih yang disematkan di kepala. Bulang tersebut terbuat dari hiou yang dibentuk dengan pola khusus dan menjadi ciri wanita dewasa dan wanita yang telah menikah di Simalungun. Tampak juga anak-anak yang telah mengenakan busana walaupun tidak mengenakan alas kaki.

\section{Gambar 10}

Penampilan Keluarga Bangsawan dari Tanohjawa, 1941

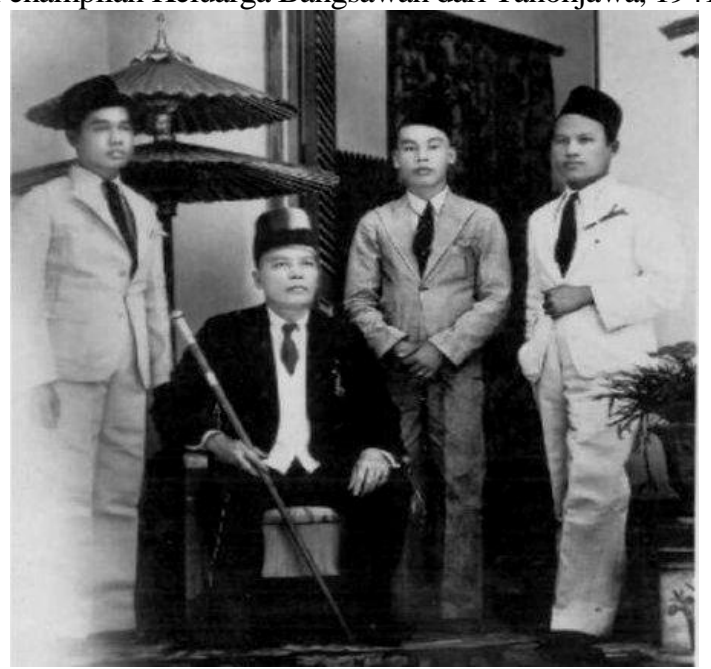

Sumber: kitlv.nl

Foto pada gambar 10 adalah keluarga bangsawan dari Tanah Jawa, Simalungun bertahun 1941. Tampak pada gambar adalah Sangma Sinaga (pegang tongkat kerajaan) dan ketiga putranya dan salah satunya adalah Kaliamsyah Sinaga, yakni putra mahkota. Pada gambar, terlihat penampilan bangsawan yang tidak mencirikan hasimalungunon tetapi telah menerima sepenuhnya kultur Barat berupa jas hitam atau putih, sepatu, dasi, celana hingga kopiah (yang melambangkan nasionalisme Indonesia). Penampilan ini tampak tegas menerima Barat yang terepresentasi pada diri Kaliamsyah Sinaga yang berperan aktif pada Negara Sumatera Timur (NST) hingga tahun 1950. Foto by design ini menunjukkan keluarga bangsawan Tanah Jawa sebagai perpaduan kelas menengah di Simalungun yang telah mendapat pendidikan kolonial yang diterima ketiga anaknya Sangma Sinaga.

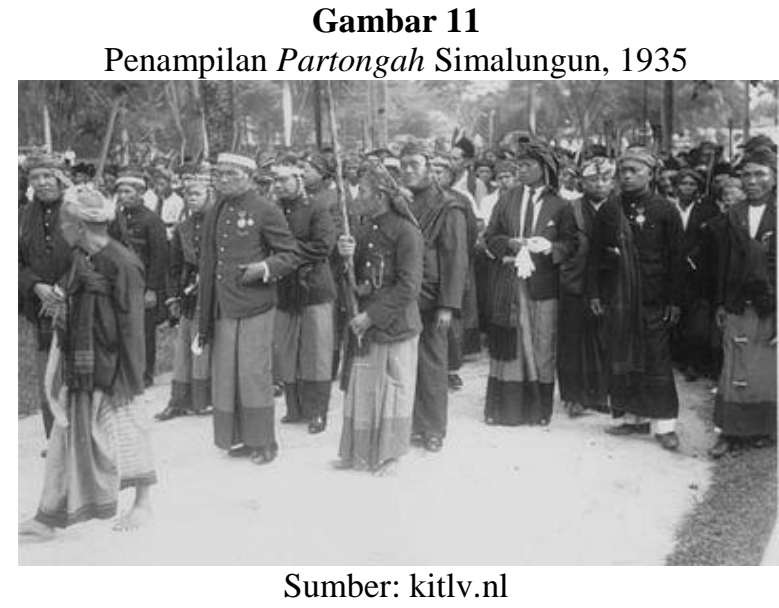

Pada gambar 11 tampak prosesi tujuh raja-raja Simalungun pada saat mendampingi penganugerahan satya lencana kesetiaan trow van dienst kepada Sawadim Damanik dari Siantar. Foto bertahun 1935 ini tampak alamiah yang di potret fotografer sewaktu prosesi. Tampak Sawadim Damanik mendapat perlindungan berupa payung kerajaan. Di barisan belakang tampak partongah (bangsawan) yang mendampinginya. Keseluruhan partongah ini mengenakan hiou ragi panei (mengganti celana), tolugbalanga dengan bros, suri-suri yang diletakkan di bahu kiri, mengenakan sepatu serta penutup kepala (gotong) yang memiliki bentuk dan motif khas serta doramani dan kelopak bunga. Antara kantung sebelah kiri dan bros memiliki rantai emas. Selain itu, tampak pula beberapa partongah mengenakan dasi dan kemeja putih yang digunakan Mogang Purba Pakpak (dari Purba). Terdapat pula pisau halasan yang disematkan di pinggang sebelah kiri. Cara berbusana seperti ini mendekati cara berbusana tradisional Simalungun dewasa ini.

Foto-foto di atas memperlihatkan tradisi berbusana yang dikenakan bangsawan Simalungun. Gaya berbusana ini menunjukkan pertemuan dan kedekatan bangsawan dengan Belanda sekaligus mendefenisikan posisi sosialnya di masyarakat. Penggunaan busana bercorak Barat ini hanya dapat terjadi karena hubungan kekuasaan, ekonomi, dan politik yang terjadi selama periode kolonialisme. Selain itu, penggunaan busana ini terkait dengan munculnya kelas menengah baru, yakni kaum terdidik lulusan sekolah Zending Jerman. Mereka ini, baik kelas partongah dan kelas terdidik merupakan pionir-pionir perubahan sosial dan kultural di Simalungun. Kenyataan ini memperlihatkan transformasi sosial yang luas (Taylor, 2005) yang bukan saja mengindikasikan tentang status melainkan juga tentang bagaimana 
cara mewujudkan atau mengalihkan kekuasaan. Busana adalah metafora kekuasaan dan wibawa (Bayly, 1986; Cohn, 1989).

Sejalan dengan kemandirian institusi etno-religius Simalungun tahun 1963, maka terbentuk keinginan untuk 'memurnikan' aspek kulturalnya dari pengaruh kebudayaan luar,yang salah satunya adalah menyangkut busana tradisionalnya. Melalui seminar kebudayaan tahun 1964,dirumuskan atribut-atribut busana tradisional Simalungun yang terdiri dari tiga komponen, yakni busana mutlak, milineris, dan aksesoris. Ketiga komponen ini dianggap mewakili ciri-ciri khusus kultur Simalungun, yakni jati diri, ekspresi, dan keagungan busanannya (Damanik, 2017b). Pada seminar ini, disepakati busana tradisional yang disebut 'asli' dari kebudayaan leluhur. Namun, menyoal tentang 'keaslian' (original) ini, sesungguhnya tidak lagi dikatakan 'asli' karena menyiratkan adanya peminjaman dan adaptasi melalui sejumlah modifikasi seperti diterangkan sebelumnya.

Keseluruhan upaya ini dilakukan sejumlah cerdik pandai (maujana) yang memiliki ahap (sense of belonging) karena dua hal: (i) Keberhasilan hidup yang dialaminya dari pendidikan kolonial maupun Zending serta pascakemerdekaan, dan (ii) Subordinasi etnik lain yang mengakibatkan marginalisasi, keterpurukan, bahkan keterbelakangan. Beberapa nama yang pantas disebut diantara maujana tersebut ialah Radjamin Purba, J. Wismar Saragih, J. Wilmar Saragih, J.P. Siboro, Djahutar Damanik, T.B.A Purba Tambak, Djason Saragih, Mansen Purba, Mailan D. Purba, D. Kenan Purba dan lain-lain (Dasuha, 2013). Busana tradisional yang dirumuskan tahun 1964 bukan hanya dipergunakan pada saat upacara (ritual) adat, tetapi juga pada momen tertentu di pemerintahan, institusi keagamaan, ataupun pertunjukan seni dan tradisi di Simalungun.

Gambar 12 di bawah ini adalah busana tradisional Simalungun. Busana mutlak pria terdiri dari penutup kepala yakni gotong tikkal (topi adat berbentuk vertikal), tolugbalanga (kemeja berupa jas lengan panjang, berwarna hitam tanpa kerah) dan saluar (celana panjang). Milieneris busana terdiri dari hiou ragi panei (kain tenunan persegi panjang dan berwarna hitam), sipatu (sepatu) dan surisuri nanggarsuasah (kain tenunan berupa selendang). Adapun aksesoris busana pria terdiri dari rattei gotong omas (rantai emas yang disematkan pada topi), doramani omas (mahkota emas), rudang hapias (mahkota dari daun palem), pisou halasan (senjata berupa keris), pita omas (pita emas yang disematkan dari kantong kiri ke kancing kemeja), kassing (kancing kemeja berupa bros), ponding (ikat pinggang), dan golang banggal omas (gelang besar). Adapun busana mutlak wanita terdiri dari bulang (topi adat yang terbuat dari kain tenunan, berwarna merah dan berliris putih), soja (kebaya), dan rok. Milieneris busana terdiri hiou ragi panei, sipatu, dan surisuri nanggarsuasah. Adapun aksesoris busana terdiri dari sutting omas (hiasan emas yang disematkan di topi), hudung-hudungan (hiasan emas yang disematkan di topi), ranttei buah banban omas (mahkota disematkan di topi), bajud (tempat sirih), sinokkod banggal (kalung emas), ponding (ikat pinggang) dan golang banggal omas (gelang besar) (Damanik, 2017b).

Gambar 12

Pakaian Mutlak, Milineris, dan Aksesoris Busana Tradisional Simalungun

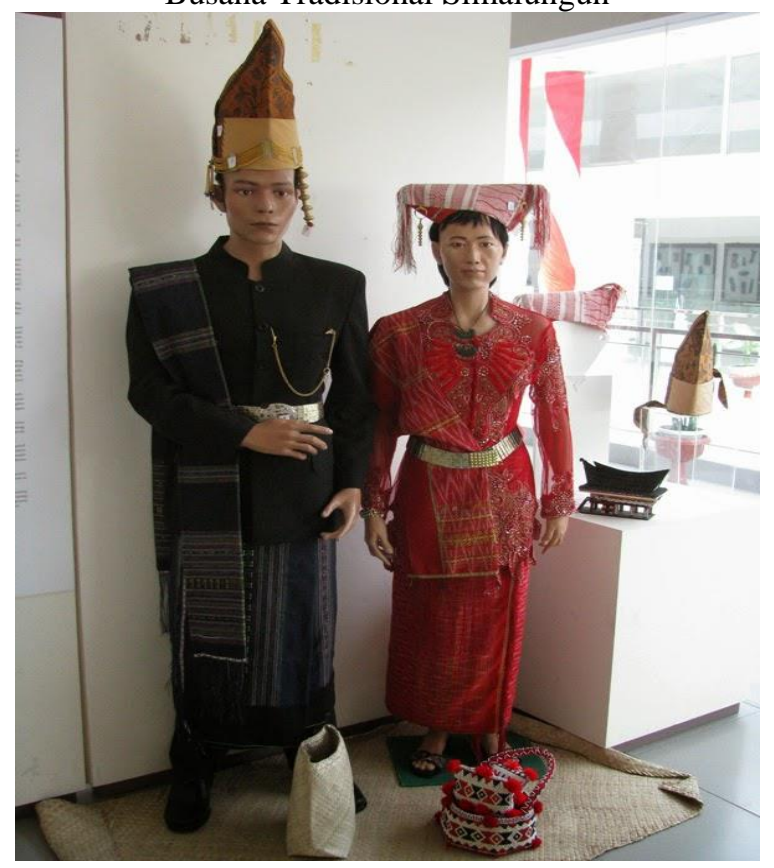

Sumber: Museum Simalungun Pematangsiantar

Dari penjelasan di atas dapat dipahami bahwa perumusan busana tradisional tidak dilakukan dengan menunjuk keaslian (orisinalitas). Perumusanbusana tradisional cenderung memperlihatkan adaptasi dan komodifikasi yang mencirikan modernitas. Sebagaimana dikemukakan Muizenberg (1990), busana tradisi bukan menunjuk pada peristiwa atau kejadian otentik dari ritual (upacara) adat istiadat, tetapi menyiratkan dorongan romantisme terhadap pelestarian kebudayaan asli. Busana tradisi 
adalah benteng tradisi (Schneider, 1987) atau kesadaran diri di atas kulit busana (Comaroff, 1992). Menurut Kuper (1973), busana adalah ekspresi identitas sosial, asal usul, komitmen dan kesetiaan individu terhadap etniknya. Jadi, busana tradisional bukan saja menunjuk pakaian nasional yang 'otentik' saja, tetapi di dalamnya menyuguhkan tindakan pelestarian kebudayaan. Inilah tuntutan UU No. 5 tahun 2017 tentang Pemajuan Kebudayaan itu. Meskipun didalamnya terdapat penyerapan kultur luar, kiranya penyerapan itu menyuguhkan makna tentang multikulturalisme yang sangat penting menemukan basis kebhinekaan Indonesia. Dari penjelasandi atas, Novelty tulisan ini menunjukkan bahwa busana menjadi salah satu alat membangun multikulturalisme. Hal ini karena busana menjadi kuali pembauran untuk melahirkan kesadaran kultural berbangsa dan bernegara yang sangat penting menjamin kelangsungan kebhinekaan di Indonesia.

\section{Penutup}

Tradisi berbusana adalah adaptasi busana dari luar yakni kultur lokal, Barat, dan ArabMelayu. Pengadaptasian dimungkinkan oleh kolonialisme, sedangkan komodifikasi dilakukan untuk mencirikan diferensiasi dan modernitas untuk menentukan posisi, peran dan kelas sosial. Karena itu, tulisan ini menyimpulkan tiga hal penting, yakni: (i) Busana tradisional adalah penampilan elitis yakni gaya berbusana yang muncul dan diperagakan dari istana yang ditularkan kepada masyarakat, (ii) Adaptasi dan komodifikasi busana, dimaksudkan sebagai diferensiasi dan redefenisi terhadap status, peran dan posisi sosial dan (iii) Perumusan busana tradisional sama sekali tidak dimaksud merujuk pada orisinalitas busana tetapi lebih kepada adaptasi dan komodifikasi sesuai particular characteristic. Namun, subtansi busana tradisional tidak terletak pada karakteristik khas yang orisinal tetapi justru pada pertarungan nilai antara atribut lokalitas dan modernitas yang kemudian membentuk makna-makna tersendiri yang melekat pada busana tradisional itu.

\section{Daftar Pustaka}

Anderson, J. (1971). Mission to the Eastcoast of Sumatra in 1823. Kuala Lumpur: Oxford University Press, Historical Reprints.

Apparudai, A. (1996). Modernity at Large: Cultural Dimensions of Globalization.
Minneapolis-London: University of Minnesota Press.

Bayly, C. (1986). The Origins of Swadesh home industry: cloth and Indian Society 17001930. In A. Appadurai (Ed.), The Social Life of things: commodities in cultural perspective (pp. 285-321). Chicago: University of Chicago Press.

Breman, J. (1992). Menjinakkan Sang Kuli: Politik Kolonial pada Awal Abad ke-20. Jakarta: Grafiti Press.

Brenner, J.F. von. (1894). Besuch bei den Kannibalen Sumatras: Erste durchquerung der unabhangigen Batak-Lande. Wurzburg: Woerl.

Cohn, B.S. (1989). Cloth, Clothes, and Colonialism. In J. Schneider (Ed.), Cloth and Human Experience (pp. 303-353). Washington, D.C.: Smitsonian Institute Press.

Comaroff, J. (1992). Ethnography and the Historical Imagination. Boulder: Westview.

Damanik, E.L. (2016). Kerajaan Siantar: dari Pulau Holang ke Kota Pematangsiantar. Medan: Simetri Institute.

Damanik, E.L. (2017a). Agama, Perubahan Sosial dan Identitas Etnik: Moralitas Agama dan Kultural di Simalungun. Medan: Simetri Institute.

Damanik, E.L. (2017b). Busana Simalungun: Politik Busana, Peminjaman Selektif dan Modernitas. Medan: Simetri Institute.

Damanik, E.L. (2018). Potret Simalungun Tempoe Doeloe: Menafsir Kebudayaan Lewat Foto. Medan: Simetri Institute.

Dasuha, J.R.P. (2003). Tole den Timorlanden das Evanggelium: Sejarah 100 Tahun Pekabaran Injil di Simalungun. Medan: Bina Media Perintis dan Kolportase GKPS.

Dasuha, J.R.P. (2013). Peradaban Simalungun: Intisari Seminar Kebudayaan Simalungun se-Indonesia Pertama tahun 1964. Pematangsiantar: Komite Penerbit Bukubuku Simalungun.

Dijk, van P. (1894). Betreffende de Sibaloengensche lanschappen Tandjoeng Kassau, Tanah Djawa en Si Antar. Tijdschrift Voor Indische Taal-, Land-En Volkenkunde, XXXVII, 145-200. 
Edwards, E. (1992). Anthropology and Photography, 1860-1920. New Haven: Yale University Press.

Fischer, C.A. (1964). Southeast Asia: A Social, Economics and Political Geography. New York: E.P. Dutton and Co. Inc.

Geertz, C. (1973). The interpretation of culture: Selected essays. New York: Basic Books.

Geertz, H. (1981). Aneka Budaya dan Komunitas di Indonesia. Jakarta: Yayasan IlmuIlmu Sosial \& FIS UI.

Gerstacker, F. (1855). Javaansche schetsen, naar het Hoogduitsch van. Bijdragen Tot de Taal- En Volkenkunde van de Koninklijk Instituuttot de Taal-, Land-En Volkenkunde, 3, 413-492.

Glazer, N. (1963). eyond Melting Pot: the Negroes, Puerto Ricans, Jews, Italians, and Irish of New York City. (2nd ed.). Cambridge: MIT and Harvard University Press.

Graaf, N. de. (1742). Beschryving van Batavia, met de szelfs kasteel en publyke gebouwen. Amsterdam: Swart.

Guillot, C. (2002). Lobutua Sejarah Awal Barus. Jakarta: Obor Indonesia dan EFEO Prancis.

Haan, F. de. (1922). Oud Batavia. (2nd ed.). Batavia: Kolff.

Hagen, D.B. (1883). Zu den Wanderungen der Battas.Das Ausland (Vol. 01). Berlin: Reimer.

Harvina. (2017). Gotong: Penutup kepala khas Simalungun. (E.L. Damanik, Ed.) (1st ed.). Banda Aceh: Kementerian Pendidikan dan Kebudayaan, Direktorat Jenderal Kebudayaan, Balai Pelestarian Nilai Budaya Aceh.

Kartodirdjo, S. (1977). Sejarah Nasional Indonesia (1st ed.). Jakarta: Balai Pustaka.

Kartodirjo, S. (1987). Perkembangan Peradaban Priyayi. Yogyakarta: Gadjah Mada University Press.

Keyser, E.D. (1922). I'ile des Seins Nus. Paris: les editions de France.

Kroesen, J. (1897). Eene reis door de landschappen Tandjoeng Kassau, Siantar en Tanah Djawa. Tijdschrift Voor Indische Taal-, Land-En Volkenkunde, XXXIX, 229-304.
Kroesen, R. . (1904). Mededeelingen betreffende het lanschap Panei en het Rajahgebied. Bijdragen Tot de Taal-, Land- En Volkenkunde van de Koninklijk Instituut, LVI, 558-586.

Kuper, H. (1973). Costume and Identity. Comparatives Studies in Society and History, 15, 348-367.

Leigh, B. (1989). Tangan-tangan trampil: Seni Kerajinan Aceh. Jakarta: Djambatan.

Lurie, A. (1992). The Language of Clothes. London: Blomsbury.

Marihandono, D. (2009). Sang Na Ualuh Damanik: Perlawanan Rakyat Simalungun Menentang Kolonialisme Belanda. Bandung: Akademia.

McGregor, K. (2008). Ketika Sejarah Berseragam: Membongkar Ideologi Militer dalam Menyusun Sejarah Indonesia. Yogyakarta: Syarikat.

Muijzenberg, O. van den. (1990). De Sociology van Zuidoost-Azie op weg naar de jaren negentig: een overzicht. In $\mathrm{H}$. S. Nordholt (Ed.), Onderzoek in ZuidoostAzie: Agendas voor de jaren negentig ( $\mathrm{p}$. 112). Leiden: Vakgroup Talen en Culturen van Zuidoost-Azie en Oceania 3.

Niessen, S.A. (1993). Batak Cloth and Clothing: A Dynamic Indonesia Tradition. New York: Oxford University Press.

Niessen, S.A. (2009). Legacy in Cloth: Batak Textiles of Indonesia. Netherland: KITLV Publications.

Nieuwenhuys, R. (1998). Tempo Doeloe: Eenzonken fotografische documenten uit het oude Indie, 1870-1920. Amsterdam: Em. Querido's Uitgeverij B.V.

Nordholdt, H.S. (2005). Outward Appearances: tren, identitas dan kepentingan. Yogyakarta: LKiS.

Nordholt, H.S. (2002). Negara di atas Kulit: Pakaian, Sepatu, dan Kerapian. In Kriminalitas, Modernitas dan Identitas dalam Sejarah Indonesia. (pp. 87-117). Yogyakarta: Pustaka Pelajar.

Nordholt, H.S. (2008). Perspektif baru penulisan sejarah Indonesia. Jakarta: Obor Indonesia.

Pamberton, J. (1994). On the Subject of Java. Ithaca: Cornell University Press. 
Parkin, H. (1978). Batak Fruit of Hindu Thought. India, Madras: The Diocesan Press.

Perret, D. (2010). Kolonialisme dan Etnisitas: Batak dan Melayu di Sumatera Timurlaut. Jakarta: KPG dan EFEO Prancis.

Perret, D. (2015). Barus Negeri Kamfer: Sejarah Perniagaan Abad 12 hingga 17 Masehi. Jakarta: KPG dan EFEO Prancis.

Reid, A. (1992). Asia Tenggara Kurun Waktu Niaga: Negeri Di atas Angin (1st ed.). Jakarta: Sinar Harapan.

Saragih, J.W. (1936). Barita ni Toean Rondahaim na ginoran ni halak Toean Raya na mabajan. Pematangraya.: Comite Na Ra Marpodah.

Schneider, J. (1987). The Anthropology of Cloth. Annual Review of Anthropology, 16, 409-448.

Schneider, J. (1989). Cloth and Human Experience. Washinton D.C: Smithsonian Instutute Press.

Simon, G. (1906). Die Arbeit de rheinische Mission auf Sumatra Ooskust. Algemeine Missions-Zeitschriff, 33, 408-417.

Smith, H.S. (1997). Aceh: Art and culture. Kualalumpur: Oxford University Press.

Taylor, J.G. (1983). The Social World of Batavia: European and Eurasian in Dutch Asia. Madison: University of Wisconsin Press.

Taylor, J.G. (1988). Weavings of power and might: the Glory of Java. Rotterdam: Museum voor Land-en Volkenkunde.
Taylor, J.G. (2005). Kostum dan Gender di Jawa Kolonial tahun 1800-1940. In H. S. Nordholdt (Ed.), Outward Appereanves: trend, identitas dan kepentingan (pp. 121-168). Yogyakarta: LKiS.

Taylor, J.G. (2008). Aceh: Narasi Foto, 18731930. In H. S. Nordholt (Ed.), Perspektif Baru Penulisan Sejarah Indonesia (pp. 313-372). Yogayakarta: Obor Indonesia, KITL-Jakarta, \& Pustaka Larasan.

Tideman, J. (1922). Simeloengen: het Land der Timoer Bataks in Zijn Vroegere isolatie en Zijn Ontwikkeling tot Een Deel van het Culturgebied van de Ooskust van Sumatera. Leiden: Louis H. Becherer.

Toer, P.A. (1988). De Pionier: Biografie van Tirto Adhisoerjo. Amsterdam: Manus Amici.

van Dijk, K. (2005). Sarung, Jubah, dan Celana: Penampilan sebagai sarana pembedaan dan diskriminasi. In H. S. Nordholt (Ed.), Outward Appeareances: trend, identitas dan kepentingan (pp. 57-120). Yogyakarta: LKiS.

Wachlin, S. (1994). Woodbury \& page photographers Java. Leiden: KITLV Press.

Weringgia, S. (1995). The politization of gender relations in Indonesia: the Indonesian womens movement and Gerwani until the New Order state. Amsterdam: University of Amsterdam.

Wilson, E. (1985). Adorned in Dreams: Fashion and Modernity. London: Virago Press. 